\title{
An Analysis Of Gender And Major Differences Upon Undergraduate Student Attitudes About Community Service Learning
}

P. K. Shukla, Chapman University, USA

Monica P. Shukla, Chapman University, USA

\begin{abstract}
Community Service Learning (CSL) believes that university and colleges should incorporate community based service projects into courses. There are faculty and administrator supporters who argue for such proposals to require community service learning components into classes, but there are also faculty and administrator critics of such proposals.

The focus of this study was to examine the attitudes of undergraduate students on community service learning. A questionnaire was given to students at a private university in Southern California to see if statistically significant differences in attitudes could be found based upon: gender, class level, major, and any prior high school community service experience. In particular, the study focuses upon the differences in attitudes between business and non-business majors as there is a perception by some non-business faculty that business students are more focused upon self-interest rather than concern for social problems.
\end{abstract}

The paper reports the findings of this study and offers policy implications/recommendations for faculty and administrators.

Keywords: Community Service Learning; Business Curriculum; Gender Differences Volunteerism

\section{INTRODUCTION}

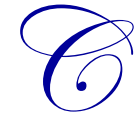

ommunity Service Learning (CSL) believes that university and colleges should incorporate community based service projects into courses. There are faculty and administrator supporters who argue for such proposals to require community service learning components into classes, but there are also faculty and administrator critics of such proposals.

Although some individuals may feel that the idea of community service learning is a new phenomenon or that it is a new fad, the idea of service learning and community service learning is rooted over several past decades as displayed in Table 1.

Table 1: Brief Historical Roots in Community Service Learning

\begin{tabular}{|l|l|}
\hline \multicolumn{2}{|c|}{ This brief historical timeline highlights some of the most important dates in the development of service-learning. } \\
\hline 1903 & Cooperative Education Movement founded at the University of Cincinnati \\
\hline Circa 1905 & William James, John Dewey developing intellectual foundations to service-based learning \\
\hline 1961 & $\begin{array}{l}\text { President John F. Kennedy establishes the Peace Corps, with authorizing legislation approved by Congress on } \\
\text { September 22, 1961 }\end{array}$ \\
1964 & $\begin{array}{l}\text { As part of the "War on Poverty," President Lyndon B. Johnson creates VISTA (Volunteers in Service to } \\
\text { America), a National Teacher Corps, the Job Corps, and University Year of Action. VISTA provides } \\
\text { opportunities for Americans to serve full-time to help thousands of low-income communities. White House } \\
\text { Fellows program established }\end{array}$ \\
\hline
\end{tabular}


Table 1 cont.

\begin{tabular}{|l|l|}
\hline 1965 & College work-study programs established \\
\hline 1966 & Urban Corps emerged, funded with federal work-study dollars \\
\hline $1966-1967$ & $\begin{array}{l}\text { "Service-learning" phrase used to describe a TVA-funded project in East Tennessee with Oak Ridge Associated } \\
\text { Universities, linking students and faculty with tributary area development organizations }\end{array}$ \\
\hline 1968 & National Service Secretariat Conference on National Service held in Washington, D.C \\
\hline 1969 & $\begin{array}{l}\text { Atlanta Service-Learning Conference (sponsors included Southern Regional Education Board, U.S. Dept. } \\
\text { HEW, City of Atlanta, Atlanta Urban Corps, Peace Corps, and VISTA) }\end{array}$ \\
\hline 1970 & The Youth Conservation Corps engages 38,000 people age 14 to 18 in summer environmental programs \\
1971 & $\begin{array}{l}\text { White House Conference on Youth report full of calls for linking service and learning. Also, the National } \\
\text { Center for Public Service Internships was established, and the Society for Field Experience Education (these } \\
\text { two merged in 1978 to become the National Society for Internships and Experiential Education) }\end{array}$ \\
\hline Circa 1971 & $\begin{array}{l}\text { National Student Volunteer Program (became the National Center for Service-Learning in 1979) established. } \\
\text { Published Synergist, a journal promoting linking service and learning }\end{array}$ \\
\hline (Source: http://www.servicelearning.org/what_is_service-learning/history)
\end{tabular}

The focus of this study was to examine the attitudes of undergraduate students on community service learning. A questionnaire was given to over 200 students (see Appendix A) at a private university in Southern California to see if statistically significant differences in attitudes could be found based upon: gender, class level, major, and any prior high school community service experience. In particular, the study focuses upon the differences in attitudes between business (77\% of respondents) and non-business majors (23\% of respondents) as there is a perception by some non-business faculty that business students are more focused upon self-interest rather than concern for social problems.

\section{SURVEY UNIVARIATE RESULTS}

A total of 209 surveys were completed by undergraduate students at Chapman University in Orange, California during the 2012/2013 academic year. Table 2 displays a breakdown of characteristics of survey respondents.

Table 2: Breakdown on Characteristics of Survey Respondents

\begin{tabular}{|l|c|c|}
\hline Total Respondents: 209 & Number of Respondents & Percentage of Respondents \\
\hline Class Level: & 2 & $1 \%$ \\
\hline Freshman & 31 & $15 \%$ \\
\hline Sophomore & 111 & $53 \%$ \\
\hline Junior & 65 & $31 \%$ \\
\hline Senior & & $77 \%$ \\
\hline Major: & 162 & $23 \%$ \\
\hline Business & 47 & \\
\hline Non-Business & & \\
\hline Gender: & 129 & $38 \%$ \\
\hline Female & 80 & \\
\hline Male & & \\
\hline Member of Club? & 86 & \\
\hline Yes & 123 & \\
\hline No & & $59 \%$ \\
\hline Did Community Service during High School? & \\
\hline Yes & 191 & $91 \%$ \\
\hline No & 18 & $9 \%$ \\
\hline Did Community Service during College Years? & & \\
\hline Yes & 156 & \\
\hline No & 53 & \\
\hline
\end{tabular}

Despite a small number of Freshmen and fewer non-business major respondents relative to the higher percentage of business major respondents, the sample size of 209 permitted a sufficient sample size to analyze the results and offer implications worthy of further consideration. 
Table 3 displays summary results of respondent attitudes with some key survey questions. The survey results display that only $31 \%$ of respondents felt that the curriculum in their major includes discussion of working in non-profit organizations. As the non-profit sector of our economy is important with employment opportunities and also with opportunities for business sector collaborations/purchases/supplies, even business students should receive greater exposure to this sector in their curriculum. In 2010, nonprofits employed 13.7 million individuals, or approximately $10 \%$ of the country's workforce. Between 2000 and 2010, nonprofit employment grew an estimated 18 percent, faster than the overall U.S. economy (Source: http://www.independentsector.org/economic_role \#sthash.LAztClGt.5nwln9VA.dpuf). Only $6 \%$ of respondents did not support the idea of having assignments in some of their classes in their major where students would have the option of working on community service learning (CSL) projects. With only $2 \%$ of respondents, there was little to no opposition to the idea of having a 3 -unit elective class in the respondent's major where students could work on community service learning. The follow-up question that asked if the respondent would have signed up for such a 3-unit elective class showed only $14 \%$ of respondents who indicated that they would not have signed up for it. Although survey indications of "yes I would have signed up for it" do not always translate into actual signups when such a class is put into the class schedule, this may be due to work and other class offering day and time conflicts. Professors should consider the incorporation or enhancement of class embedded assignment opportunities for students to work with non-profit organizations. Undergraduate curriculum committees should consider adding elective courses within majors where students can perform community service projects; respondents seem to indicate that "if you offer it, we will sign up."

Table 3: Respondent Attitudes with Some Key Survey Questions

\begin{tabular}{|c|c|c|c|c|c|}
\hline & SA & $\mathbf{A}$ & $\mathbf{N}$ & D & SD \\
\hline $\begin{array}{l}\text { The curriculum in my major includes discussion of working in non-profit } \\
\text { organizations. }\end{array}$ & $8 \%$ & $23 \%$ & $33 \%$ & $31 \%$ & $5 \%$ \\
\hline $\begin{array}{l}\text { I would support the idea of having assignments in some of classes in my major } \\
\text { where students would have the option of working on community service projects. }\end{array}$ & $36 \%$ & $37 \%$ & $21 \%$ & $4 \%$ & $2 \%$ \\
\hline $\begin{array}{l}\text { I would support the idea of having a } 3 \text {-unit elective class in my major where } \\
\text { students can work on community service projects. }\end{array}$ & $44 \%$ & $41 \%$ & $13 \%$ & $2 \%$ & $0 \%$ \\
\hline & Yes & No & Not Sure & & \\
\hline $\begin{array}{l}\text { If a 3-unit elective class was offered in my major to work on community service } \\
\text { projects, I would/would have signed up for it. }\end{array}$ & $65 \%$ & $14 \%$ & $21 \%$ & & \\
\hline
\end{tabular}

The preliminary univariate analysis on responses to individual questions was followed up with later multivariate analysis of key variables in the survey. The following are some key findings based upon Crosstabulations and Chi-Square Tests of statistical significance.

\section{SURVEY MULTIVARIATE RESULTS/IMPLICATIONS}

Class level was not statistically significant in whether the respondent had done any community service work during their college years; more Freshmen should be included in the samples of future studies to verify this result, as this study had only $1 \%$ freshmen respondents.

Class level was not statistically significant in whether the respondent supported the idea of having assignments in classes that offered the option of CSL assignments; more Freshmen should be included in the samples of future studies to verify this result, as this study had only $1 \%$ freshmen respondents.

Class level was not statistically significant in whether the respondent supported the idea of having a 3-unit elective class in their major where students could work on CSL projects; more Freshmen should be included in the samples of future studies to verify this result, as this study had only $1 \%$ freshmen respondents.

Respondent major was significantly related to whether they were a member of a student club or not (at the 0.000 level in a Chi-Square Test). $68 \%$ of business majors were not a member of a student organization, whereas only $25 \%$ of non-business majors were not members of a student organization.

Respondent major was not significantly related to whether or not they did any CSL during their high school years as $91 \%$ of respondents did some CSL during their high school years; as more high schools require some documented CSL, only 9\% of all respondents indicated that they did not do any CSL during high school. 
Respondent major was slightly related to whether or not they did any CSL during their college years (at the 0.061 level in a Chi-Square Test) with a lower percentage of business majors indicating that they had done CSL (71\%) during college compared to non-business majors indicating that they had done CSL (85\%). This result fits the perception that business majors are less interested in volunteerism activities.

Respondent major was not significantly related to whether or not the respondent supported the idea of having assignments in some of their classes in their major where they had the option of working on CSL projects. Respondent major was also not significantly related to whether or not the respondent supported the idea of having a 3-unit elective in their major to work on CSL projects. With the wording of the survey as the assignments in the classes being an "option" and as the 3-unit CSL class would be an "elective" this explains why there would be little opposition to the ideas even by business majors.

For the follow-up question on a 3-unit elective class offered, respondent major was significantly related to whether the respondent would sign up for such a class or not (at the 0.011 level in a Chi-Square Test). $17 \%$ of business majors indicated that they would not sign up for such a class, whereas only $2 \%$ of non-business majors indicated that they would not take such a class. Business school curriculum committees should consider offering such a class on a "special topics" or experimental designation to assess their business student interest prior to making such a class part of the regular every semester offering. For non-business school curriculum committees, there seems to be less risk in offering such an elective course.

Respondent gender was slightly related to whether or not they were a member of a student organization during their college years (at the 0.068 level in a Chi-Square Test) with a lower percentage of males indicating joining a student club (33\%) compared to females (45\%).

Respondent gender was not significantly related to whether or not they did any CSL during their high school years as $91 \%$ of respondents did some CSL during their high school years; as more high schools require some documented CSL, only $9 \%$ of all respondents indicated that they did not do any CSL during high school.

Respondent gender was significantly related to whether or not they did any CSL during their college years (at the 0.004 level in a Chi-Square Test) with a lower percentage of males indicating that they had done CSL (63\%) during college compared to females indicating that they had done CSL (81\%). This result fits the perception that females are more interested in volunteerism activities than males.

Respondent gender was significantly related to whether or not the respondent supported the idea of having assignments in some of their classes in their major where they had the option of working on CSL projects (at the 0.026 level in a Chi-Square Test). Female respondents favored the idea of CSL class assignments more than male respondents.

Respondent gender was not significantly related to whether or not the respondent supported the idea of having a 3-unit elective in their major to work on CSL projects. This result could be explained by the low $2 \%$ of all respondents opposed to the idea of offering a 3 -unit elective class.

For the follow-up question on a 3-unit elective class offered, respondent gender was significantly related to whether the respondent would sign up for such a class or not (at the 0.003 level in a Chi-Square Test). $23 \%$ of male respondents indicated that they would not sign up for such a class, whereas only $9 \%$ of female respondents indicated that they would not take such a class. These results along with the prior two gender results support the perception that females are more interested in volunteerism than males.

\section{CONCLUSIONS}

The multivariate analysis indicates that class level, major, and gender do have impacts upon student CSL activities during college and/or their attitudes about offering the option of CSL assignments in classes in their major or the offering of a 3-unit elective in their major for CSL projects. Although most respondents indicate supporting the idea of classroom CSL assignment "options" and a 3-unit CSL project "elective" course, there are fewer 
respondents who indicated that they would actually sign up themselves for such a class offered. College professors should find little resistance to offering students the option of CSL projects in their classes and curriculum committees also should find sufficient levels of interest with majors on their campuses to offer at least one 3-unit elective course on CSL projects initially on a trial or experimental basis. The results support some of the perceptions that business majors are less interested in volunteerism than non-business majors and that females are more interested in volunteerism than males.

\section{AUTHOR INFORMATION}

Dr. P. K. Shukla is an Associate Professor of Management at the Argyros School of Business and Economics at Chapman University. He has served previously as Director of the Leatherby Center for Entreprenurship and as Vice Chancellor for Entrepreneurship at Chapman University. He has consulted to businesses and has served on boards of directors of organizations in addition to serving on the editorial review board of academic journals. His Ph.D. is from the University of California, Los Angeles and he has a Master's of Science Degree in Business Administration from the University of Southern California. E-mail: shukla@chapman.edu (Corresponding author)

Monica Shukla is a Doctoral Candidate at Chapman University and is an Assistant Professor of Business at Brandman University in Irvine, California. Her dissertation focuses upon an examination of best practices in the use of social media by higher education institutions including an analysis of return on investment measurement approaches. She has served in managerial positions in higher education and has entrepreneurial experience with her own consulting firm. She has Master's Degrees in Human Resources Management and also in Organizational Leadership. She also has a Graduate Certificate in Non-Profit Leadership.

\section{REFERENCES}

1. http://www.independentsector.org/economic_role\#sthash.LAztClGt.5nwln9VA.dpuf

2. http://www.servicelearning.org/what_is)service-learning/history 


\section{APPENDIX A：UNDERGRADUATE STUDENT SURVEY ON COMMUNITY SERVICE LEARNING}

\section{Undergraduate Student Survey: Attitudes about Community Service Learning}

This is a survey to determine student attitudes about "community service learning." Community service learning is the term applied to having courses and course assignments for students that involve learning via working on community service (assisting non-profit organizations) projects.

1. Your class level: [ ] Freshman [ ] Sophomore [ ]Junior [ ] Senior

2. Your major:

3. Your gender: [ ] Male [ ] Female

4. Are you a member of a student club(s) on campus? [ ] yes [ ] no

5. Have any of your clubs (or club) done any service activity for the off-campus community?
[ ] yes
[ ] no
[ ] don't know
[ ] not a member of any club

6. During your high school years, did you do any community service work or volunteer with some non-profit organization?
[ ] yes
[ ] no

7. During your college years, so far, have you done any community service work or volunteer work with some non-profit organization?

[ ] yes [ ] no

For the following statements, circle if you:

$\begin{array}{ll}\text { SA } & \text { Strongly Agree } \\ \text { A } & \text { Agree } \\ \text { N } & \text { Neutral } \\ \text { D } & \text { Disagree } \\ \text { SD } & \text { Strongly Disagree }\end{array}$

8. The curriculum in my major includes discussion of ethics for graduates in my major.
SA
A
$\mathrm{N}$
$\mathrm{D}$
SD

9. The curriculum in my major includes discussion of working in non-profit organizations.
SA
A
$\mathrm{N}$
$\mathrm{D}$
SD

10. I would support the idea of having assignments in some of classes in my major where students would have the option of working on community service projects.
SA
A
$\mathrm{N}$
D SD

11. I would support the idea of having a 3-unit elective class in my major where students can work on community service projects.
SA A
$\mathrm{N}$
D SD

12. If a 3-unit elective class was offered in my major to work on community service projects, I would/would have signed up for it.

$$
\text { [ ] yes [ ] no [ ] not sure }
$$

